\title{
SHORT REPORT: POLYMORPHISMS IN THE CHLOROQUINE RESISTANCE TRANSPORTER GENE IN PLASMODIUM FALCIPARUM ISOLATES FROM LOMBOK, INDONESIA
}

\author{
MARIA CECILIA HUAMAN, KAZUMI YOSHINAGA, AAN SURYANATHA, NYOMAN SUARSANA, AND \\ HIROJI KANBARA \\ Institute of Tropical Medicine, Nagasaki University, Sakamoto, Nagasaki, Japan; Instituto de Medicina Tropical Alexander \\ von Humboldt, Universidad Peruana Cayetano Heredia, Lima, Peru; Meninting Health Center, West Lombok, Indonesia
}

\begin{abstract}
The polymorphisms in the Plasmodium falciparum multidrug resistance 1 (pfmdr1) and P. falciparum chloroquine resistance transporter $(p f c r t)$ genes, which are associated with chloroquine resistance, were examined in 48 $P$. falciparum isolates from uncomplicated malaria patients from the West Lombok District in Indonesia. The point mutation $\mathrm{N} 86 \mathrm{Y}$ in $p f m d r 1$ was present in $35.4 \%$ of the isolates and mutation K76T in pfcrt was found in all but one of the samples studied. Identified pfcrt haplotypes were mainly identical to the Papua New Guinea type $\mathrm{S}_{\text {agt }}$ VMNT (42 of $48,87.5 \%$ ), and a few isolates had the Southeast Asia type CVIET (5 of 48, 10.4\%). Moreover, one P. falciparum isolate harbored the $\mathrm{K} 76 \mathrm{~N}$ mutation, giving rise to the haplotype CVMNN, which was not previously reported in field isolates. Our findings suggest that chloroquine resistance in this area might have the same origin as in Papua New Guinea.
\end{abstract}

The mechanism of chloroquine (CQ) resistance in Plasmodium falciparum has been investigated and mutations in the $P$. falciparum CQ resistance transporter gene ( $p f c r t)$ located on chromosome 7 , and the $P$. falciparum multidrug resistant gene 1 (pfmdr1), located on chromosome 5, have been implicated. The substitution of threonine for lysine in codon 76, $\mathrm{K} 76 \mathrm{~T}$ in the pfcrt gene, was shown in vitro to be associated with CQ resistance in isolates from Asia, Africa, South America, and Papua New Guinea. ${ }^{1,2}$ Sequence polymorphisms at position $72-76$ of this gene have been associated with the geographic origin of parasite samples, with the CVIET pattern in resistant isolates from Asia and Africa, and with SVMNT in resistant isolates from Papua New Guinea and South America. ${ }^{1,3}$ The multidrug resistant gene $p f m d r 1$ with a mutation of asparagine to tyrosine at position 86 (N86Y) has been associated with in vitro resistant strains. ${ }^{4}$ Although its participation is not clear, it has been suggested that the pfmdr1 mutation may confer some advantage to the parasite in the presence of $\mathrm{CQ}$, thus increasing the level of $\mathrm{CQ}$ resistance. $^{2,5}$ Furthermore, a recent study that included samples from four countries of Southeast Asia described the mutations N86Y in pfmdr1 and K76T in pfcrt genes as molecular markers for predicting clinical outcome of CQ treatment. ${ }^{6}$

In Indonesia, the first cases of resistance were reported in the early 1970s from Kalimantan and Irian Jaya. Although resistance has been reported on several islands in Indonesia, ${ }^{7}$ with resistance as high as $95 \%$ for $P$. falciparum and $84 \%$ for $P$. vivax, ${ }^{8} \mathrm{CQ}$ continues to be the first-line treatment of $P$. falciparum and $P$. vivax malaria because of its safety and availability at very low cost. Here we examined the prevalence of polymorphisms in the pfmdrl and pfcrt genes in 48 $P$. falciparum isolates from the West Lombok District of Indonesia. In addition, the possible origin of $\mathrm{CQ}$ resistance in Indonesia is discussed.

Blood samples were collected from 48 patients with uncomplicated $P$. falciparum malaria in sub-district Batulayar in West Lombok in the West Nusa Tenggara Province of Indonesia (Figure 1) from June to September 2002. Sub-district Batulayar has a population of approximately 35,658. The climate is tropical and malaria transmission occurs more frequently during dry season between April and October, although low-level transmission occurs throughout the year, es- pecially in the hilly-forested ranges of Sidemen to Pusuk. Cases of $P$. falciparum and $P$. vivax malaria and a few cases of $P$. malariae malaria have been reported in the area. The recommended first-line treatment is CQ, $25 \mathrm{mg} / \mathrm{kg}$ given over a three-day period. When a treatment failure occurs, the combination of sulfadoxine/pyrimethamine is prescribed. Inclusion criteria were a fever $\geq 37.5^{\circ} \mathrm{C}$ during the last 48 hours and a positive result in the NOW ICT $^{\circledR}$ (Binax, Portland, ME) rapid malaria test. Blood samples were collected on filter paper and transported to the Muninting district health center laboratory for malaria testing. Samples positive for $P$. falciparum malaria were processed thereafter in Japan at the Department of Protozoology of Nagasaki University. Informed consent was obtained from each individual. The study was reviewed and approved by the ethical committee of the Institute of Tropical Medicine of Nagasaki University and the executive committee of the Malaria Control Project in Lombok and Sumbawa under the Japanese International Cooperation Agency partnership program.

The DNA was extracted from filter paper by cutting the blood spot into pieces and soaking them in $0.5 \%$ saponin in HBS buffer (140 mM NaCl, $10 \mathrm{mM} \mathrm{KCl,} 10 \mathrm{mM}$ HEPES, pH 7.2). Thereafter, the QIAamp DNA Kit (Qiagen, Valencia, CA) was used according to the manufacturer's instructions. The parasite lines FCR3 and K1 were used as controls for the detection of polymorphism at position 86 in $p f m d r 1$ and direct sequencing analysis of pfcrt gene. For genotyping of the glutamate-rich protein (glurp) gene, strains K1 and 3D7 were used as controls in the amplification.

To determine the presence of tyrosine at position 86 in pfmdr1, a nested polymerase chain reaction (PCR)-restriction fragment length polymorphism protocol was used as previously described. ${ }^{9}$ Digestion with the restriction endonuclease Apo I (New England Biolabs, Inc., Beverly, MA) detects tyrosine at position 86 after resolution of the products by electrophoresis on 1-3\% agarose gels (Nusieve 3:1; BioWhittaker Molecular Applications, Rockand, ME). For pfcrt gene analysis, a first amplification was carried out with previously designed primers, ${ }^{9}$ and the products obtained were used as a template in a nested PCR encompassing the polymorphic codons $72-76$ and 97 in exon 2 as previously reported. ${ }^{3}$ The PCR amplification products were purified using the QIAquick 


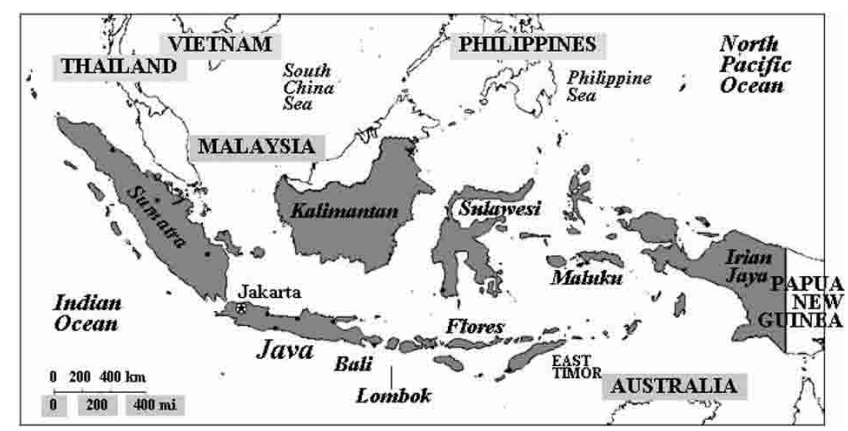

FIGURE 1. Map of Indonesia showing the location of Lombok.

PCR purification kit (Qiagen) and directly sequenced on an ABI310 automated sequencer using ABI PRISM Big Dye Terminator Cycle kit (Applied Biosystems, Foster City, CA) following the manufacturer's instructions.

The glurp gene, located on chromosome 11, which has a high degree of polymorphism, was assessed for evaluation of diversity of the $P$. falciparum isolates population in the region. ${ }^{10}$ The amplification products were resolved by electrophoresis on a $1 \%$ agarose gel and stained with ethidium bromide. The glurp amplification product sizes were estimated using DNAfrag version 3.03 Software (John Nash, Institute for Biologic Sciences, National Research Council of Canada, Ottawa, Ontario, Canada). For comparisons, Fisher's exact test was used.

Seventeen isolates $(35.4 \%)$ had the $86 \mathrm{Y}$ mutation in the pfmdrl gene, 26 had wild type N86, and 5 carried both alleles (Table 1). In previous studies in Irian Jaya and West Papua, N86Y was found to show a correlation with CQ-resistant $P$. falciparum parasites. ${ }^{11,12}$ The mutation K76T in the pfcrt gene was found in all but one (47 of $48,97.9 \%$ ) of the isolates studied. A previous report showed that the K76T mutation showed a correlation with clinical resistance to $\mathrm{CQ}$ and as a molecular marker had a sensitivity of $93 \%$ and a specificity of $82 \% .{ }^{13}$ Both point mutations in the $p f m d r 1$ and $p f c r t$ genes have been proposed to indicate a tendency toward reduced susceptibility to CQ. Thus, our results suggest potential CQ resistance in the region, although other factors may influence the final treatment outcome. The combination of geographic remoteness to health facilities and lack of interest in seeking medical attention driven by both financial reasons and lack of knowledge resulted in an overall follow-up rate of $23 \%$ (11 of 48). After 14 days of CQ treatment, 5 of 11 patients were not able to clear the parasites, and had tendency to harbor $86 \mathrm{Y}$ in the $p f m d r 1$ gene (Table 1). However, a larger sample size is required to obtain conclusive results.

A new mutation, $\mathrm{K} 76 \mathrm{~N}$, which substitutes asparagine for lysine, was found in one isolate from the sub-village Pusuk, generating the haplotype CVMNN. For confirmation of this finding, independent PCR amplifications and at least three repetitions of sequencing were carried out. In all cases, unambiguous electropherograms were obtained, showing AAT that codes for asparagine at position 76 . The K76N mutation could be misidentified as a K76T substitution by a PCRrestriction enzyme protocol. ${ }^{14}$ To our knowledge, this is the first time that $\mathrm{K} 76 \mathrm{~N}$ has been reported in a field study. However, it has been reported in laboratory experiments after exposure of parasites to lethal concentrations of CQ. In those experiments, Cooper and others demonstrated that the $\mathrm{K} 76 \mathrm{~N}$ mutation confers the verapamil-reversible CQ-resistance phenotype associated with greatly reduced accumulation of the drug. ${ }^{15}$ Contrary to those in vitro experiments, the patient possessing this rare pfcrt haplotype cleared parasites after treatment with CQ. Since other factors participate in the clinical outcome, it would be interesting to look for more isolates with CVMNN and carry out the in vitro susceptibility test.

The sequence analysis of codons 72-76 in the pfcrt gene (Table 1) allowed identification of previously reported haplotypes $\mathrm{S}_{\mathrm{agt}}$ VMNT (42 of 48, 87.5\%) and CVIET (5 of 48, $10.4 \%$ ). The pfcrt SVMNT haplotype with serine coded by AGT has been found in Bougainville, Papua New Guinea, ${ }^{16}$

TABLE 1

Genotypes for Pfcrt, Pfmdr1, and Glurp genes in 48 Plasmodium falciparum isolates from Lombok, Indonesia*

\begin{tabular}{|c|c|c|c|c|}
\hline Subvillage & $\begin{array}{c}P f c r t \\
\text { haplotype } \dagger\end{array}$ & $\begin{array}{l}\text { Codon } 86 \text { in } \\
\text { Pfmdr1 }\end{array}$ & $\begin{array}{c}\text { Glurp } \\
\text { genotypeł }\end{array}$ & $\begin{array}{l}\text { Parasite } \\
\text { clearance } \\
\text { at } 14 \text { days }\end{array}$ \\
\hline Bunean & SVMNT & Tyr and Asn & 650 & Failure \\
\hline Bunean & SVMNT & Tyr & 750 & Failure \\
\hline Batu Penyu & SVMNT & Tyr & 750 & Failure \\
\hline Batu Penyu Atas & SVMNT & Asn & 750 & Failure \\
\hline Pelolat & SVMNT & Tyr & 1000 & Failure \\
\hline Kedondong Atas & SVMNT & Asn & 700 & Success \\
\hline Batu Penyu & SVMNT & Tyr & 750 & Success \\
\hline Batulayar & SVMNT & Asn & 700 & Success \\
\hline Pusuk & CVMNN & Asn & 950 & Success \\
\hline Senggigi & SVMNT & Asn & 700 & Success \\
\hline Senggigi & SVMNT & Asn & 700 and 850 & Success \\
\hline Penanggak & SVMNT & Asn & 600 & ND \\
\hline Penanggak & SVMNT & Asn & 800 & ND \\
\hline Penanggak & SVMNT & Tyr & 900 & ND \\
\hline Penanggak & SVMNT & Asn & 1100 & ND \\
\hline Penanggak & SVMNT & Asn & 1000 & ND \\
\hline Penanggak & SVMNT & Tyr & 900 & ND \\
\hline Kekeran & SVMNT & Tyr & 450 & ND \\
\hline Kekeran & SVMNT & Tyr & 750 & ND \\
\hline Kekeran & SVMNT & Asn & 900 & ND \\
\hline Kekeran & SVMNT & Asn & 700 & ND \\
\hline Sidemen Daye & CVIET & Tyr & 450 & ND \\
\hline Sidemen Daye & SVMNT & Asn & 900 & ND \\
\hline Sidemen Lauk & SVMNT & Asn & 750 & ND \\
\hline Sidemen Lauk & SVMNT & Asn & 550 & ND \\
\hline Sidemen Lauk & SVMNT & Tyr & 550 & ND \\
\hline Seraye & SVMNT & Asn & 700 & ND \\
\hline Seraye & SVMNT & Asn & 600 & ND \\
\hline Seraye & SVMNT & Asn & 600 & ND \\
\hline Kodondong Atas & SVMNT & Asn & 700 & ND \\
\hline Kedondong Atas & CVIET & Tyr & 450 & ND \\
\hline Kedondong Atas & CVIET & Tyr & 450 & ND \\
\hline Kedondong Atas & CVIET & Tyr & 450 & ND \\
\hline Kedondong Atas & SVMNT & Tyr & 900 & ND \\
\hline Kedondong Atas & CVIET & Tyr and Asn & 450 & ND \\
\hline Apit Aik & SVMNT & Tyr and Asn & 750 & ND \\
\hline Apit Aik & SVMNT & Asn & 750 & ND \\
\hline Apit Aik & SVMNT & Asn & 800 & ND \\
\hline Batu Bolong & SVMNT & Asn & 750 & ND \\
\hline Batu Bolong & SVMNT & Asn & 650 & ND \\
\hline Batu Penyu & SVMNT & Tyr & 750 & ND \\
\hline Batu Penyu & SVMNT & Asn & 750 & ND \\
\hline Batu Penyu Atas & SVMNT & Tyr & 750 & ND \\
\hline Batu Penyu Atas & SVMNT & Asn & 750 & ND \\
\hline Duduk Atas & SVMNT & Tyr and Asn & 600 & ND \\
\hline Duduk Atas & SVMNT & Asn & 950 & ND \\
\hline Duduk Atas & SVMNT & Tyr & 1000 & ND \\
\hline Sd. Kedondong & SVMNT & Tyr and Asn & 700 & ND \\
\hline
\end{tabular}

$* P f c r t=P$. falciparum chloroquine resistance transporter; $P f m d r 1=P$. falciparum mul tidrug resistance 1; Glurp $=$ glutamine-rich protein; $\mathrm{ND}=$ no data.

$\dagger$ Codons $72-76$ in Pfcrt gene.

Polymerase chain reaction product sizes in basepairs. 
the main island of Papua New Guinea, ${ }^{3}$ and East Timor. ${ }^{17}$ The haplotype CVIET has been reported in countries of Southeast Asia. ${ }^{1,18}$ Since Lombok, Indonesia is located near Papua New Guinea (Figure 1), it is not unexpected that both the SVMNT and CVIET haplotypes were detected.

Furthermore, in our attempt to evaluate the diversity among the isolates studied, we assessed the glurp gene and 11 glurp genotypes were found in West Lombok, ranging from 450 to 1,100 basepairs. The West Lombok District, despite its small area, shows a high degree of diversity in the $P$. falciparum population that might be a product of high rate of transmission of malaria or human transmigration.

Upon examination for any linkage among the alleles studied in the $p f m d r 1, p f c r t$, and glurp genes, significant associations were found between the pfcrt CVIET haplotype and pfmdr1 86Y $(P=0.0193)$, the CVIET haplotype and glurp $450(P<0.001)$, and pfmdr1 86Y and glurp $450(P=0.0057)$. Our findings showed that the majority of isolates have $p f c r t$ haplotype SVMNT, pfmdr1 86N, and glurp with molecular masses greater than 450 homogeneously distributed in all the villages from West Lombok, indicating that these might be indigenous in the area. A few isolates harboring pfcrt haplotype CVIET, pfmdrl 86Y, and glurp 450, found mainly in Kedondong Atas village, were most likely introduced recently. Therefore, CQ resistance in Lombok might have the same origin as the Papua New Guinea strains, and the Southeast Asian pfcrt haplotype CVIET might have been introduced only recently in a particular region. Further studies are being carried out in isolates from Lombok and other Indonesian islands to determine the prevalence of the novel $\mathrm{K} 76 \mathrm{~N}$ mutation and its association with clinical outcome/in vitro susceptibility to CQ.

Received December 16, 2003. Accepted for publication February 4, 2004.

Acknowledgments: We are grateful to the Case Detection and Treatment Team at the Meninting Health Center (West Lombok, Indonesia) for their collaboration in this study.

Financial support: This study was partially supported by the Japanese International Cooperation Agency partnership program, and by grant for International Health Cooperation Research (13-C-5) from the Ministry of Health, Labor and Welfare. Maria Cecilia Huaman is the recipient of the Monbusho scholarship awarded by the Ministry of Education, Science, Sports and Culture of the Government of Japan.

Authors' addresses: Maria Cecilia Huaman, Institute of Tropical Medicine, Nagasaki University, Sakamoto 1-12-4, Nagasaki 852-8523, Japan and Instituto de Medicina Tropical Alexander von Humboldt, Universidad Peruana Cayetano Heredia, Lima, Peru, E-mail: ceci_ huaman@yahoo.com. Kazumi Yoshinaga and Hiroji Kanbara, Institute of Tropical Medicine, Nagasaki University, Sakamoto 1-12-4, Nagasaki 852-8523, Japan, Telephone: 81-95-849-7838, Fax: 81-95849-7805. E-mail: f0512@cc.nagasaki-u.ac.jp. Aan Suryanatha and Nyoman Suarsana, Meninting Health Center, West Lombok, Indonesia.

\section{REFERENCES}

1. Fidock DA, Nomura T, Talley AK, Cooper RA, Dzekunov SM, Ferdig MT, Ursos LMB, Singh Sidhu AB, Naude B, Deitsch KW, Su XZ, Wootton JC, Roepe PD, Wellems TE, 2000. Mutations $\mathrm{n}$ the $P$. falciparum digestive vacuole transmembrane protein PfCRT and evidence for their role in chloroquine resistance. Mol Cell 6: 861-871.

2. Djimde A, Doumbo OK, Cortese JF, Kayentao K, Doumbo S, Diourte Y, Dicko A, Su XZ, Nomura T, Fidock DA, Wellems TE, Plowe CV, 2001. A molecular marker for chloroquineresistant falciparum malaria. $N$ Engl J Med 344: 257-263.
3. Mehlotra RK, Fujioka H, Roepe PD, Janeeh O, Ursos LMB, Jacobs-Lorena V, McNamara DT, Bockarie MJ, Kazura JW, Kyle DE, Fidock DA, Zimmerman PA, 2001. Evolution of a unique Plasmodium falciparum chloroquine-resistance phenotype in association with pfcrt polymorphism in Papua New Guinea and South America. Proc Natl Acad Sci USA 98: 12689-12694.

4. Foote SJ, Kyle DE, Martin RK, Oduola AM, Forsyth K, Kemp DJ, Cowman AF, 1990. Several alleles of the multidrugresistance gene are closely linked to chloroquine resistance in Plasmodium falciparum. Nature 345: 255-258.

5. Babiker HA, Pringle SJ, Abdel-Muhsin A, Mackinnon M, Hunt P, Walliker D, 2001. High-level chloroquine resistance in Sudanese isolates of Plasmodium falciparum is associated with mutations in the chloroquine resistance transporter gene $p$ fcrt and the multidrug resistance gene pfmdr1. J Infect Dis 183: 1535-1538.

6. Pickard AL, Wongsrichanalai C, Purfield A, Kamwendo D, Emery K, Zalewsky C, Kawamoto F, Miller RS, Meshnick. 2003. Resistance to antimalarials in southeast Asia and genetic polymorphisms in pfmdr1. Antimicrobial Agents Chemother 47: 2418-2423.

7. World Health Organization, 1990. The Clinical Management of Acute Malaria. Third edition. New Dehli: World Health Organization. Regional Publications, South East Asia Series No. 9.

8. Sumawinata IW, Bernadeta, Leksana B, Sutamihardja A, Purnomo, Subianto B, Sekartuti, Fryauff DJ, Baird JK. 2003. Very high risk of therapeutic failure with chloroquine for uncomplicated Plasmodium falciparum and Plasmodium vivax malaria in Indonesian Papua. Am J Trop Med Hyg 68: $416-420$.

9. Huaman MC, Roncal N, Nakazawa S, Long TTA, Gerena L, Garcia C, Solari L, Magill AJ, Kanbara H, 2004. Polymorphism of the Plasmodium falciparum multidrug resistance 1 and chloroquine resistance transporter genes and in vitro susceptibility to aminoquinolines in isolates from the Peruvian Amazon. Am J Trop Med Hyg 70: 1-6.

10. Viriyakosol S, Siripoon N, Petcharapirat C, Petcharapirat P, Jarra W, Thaithong S, Brown KN, Snounou G, 1995. Genotyping of Plasmodium falciparum isolates by the polymerase chain reaction and potential uses in epidemiological studies. Bull World Health Organ 73: 85-95.

11. Gomez-Saladin E, Fryauff DJ, Taylor WR, Laksana BS, Susanti AI, Purnomo, Subianto B, Richie TL. 1999. Plasmodium falciparum mdr1 mutations and in vivo chloroquine resistance in Indonesia. Am J Trop Med Hyg 61: 240-244.

12. Nagesha HS, Din-Syafruddin, Casey GJ, Susanti AI, Fryauff DJ. 2001. Mutations in the pfmdrl, dhfr and dhps genes of Plasmodium falciparum are associated with in vivo drug resistance in West Papua, Indonesia. Trans R Soc Trop Med Hyg 95: 43-49.

13. Maguire DJ, Susanti AI, Krisin, Sismadi P, Fryauff DJ, Baird JK. 2001. The T76 mutation in the pfcrt gene of Plasmodium falciparum and clinical chloroquine resistance phenotypes in Papua, Indonesia. Ann Trop Med Parasitol 95: 559-572.

14. Plowe C, 2002. University of Maryland, Baltimore, MD. Web site: http://medschool.umaryland.edu/cvd/2002_pcr_asra.htm.

15. Cooper RA, Ferdig MT, Su XZ, Ursos LMB, Mu J, Nomura T, Fujioka H, Fidock DA, Roepe PD, Wellems TE, 2002. Alternative mutations at position 76 of the vacuolar transmembrane protein PfCRT are associated with chloroquine resistance and unique stereospecific quinine and quinidine responses in Plasmodium falciparum. Mol Pharmacol 61: 35-42.

16. Chen N, Russell B, Staley J, Kotecka B, Nasveld P, Cheng Q, 2001. Sequence polymorphisms in $p f c r t$ are strongly associated with chloroquine resistance in Plasmodium falciparum. J Infect Dis 183: 1543-1545.

17. Chen N, Baker J, Ezard N, Burns M, Edstein MD, Cheng Q, 2002. Molecular evaluation of the efficacy of chloroquine treatment of uncomplicated Plasmodium falciparum malaria in East Timor. Am J Trop Med Hyg 67: 64-66.

18. Lim P, Chy S, Ariey F, Incardona S, Chim P, Sem R, Denis MB Hewitt S, Hoyer S, Socheat D, Merecreau-Puijalon O, Fandeur T, 2003. Pfcrt polymorphism and chloroquine resistance in Plasmodium falciparum strains isolated in Cambodia. Antimicrobial Agents Chemother 47: 87-94. 